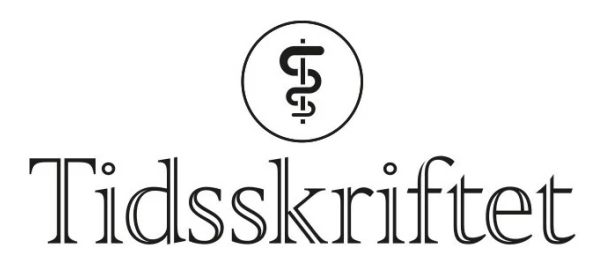

DEN NORSKE LEGEFORENING

\title{
Glimrende oppdatering i psykiatri
}

\author{
ANMELDELSER
}

PER VAGLUM

Universitetet i Oslo

Professor emeritus, Avdeling for medisinsk atferdsvitenskap

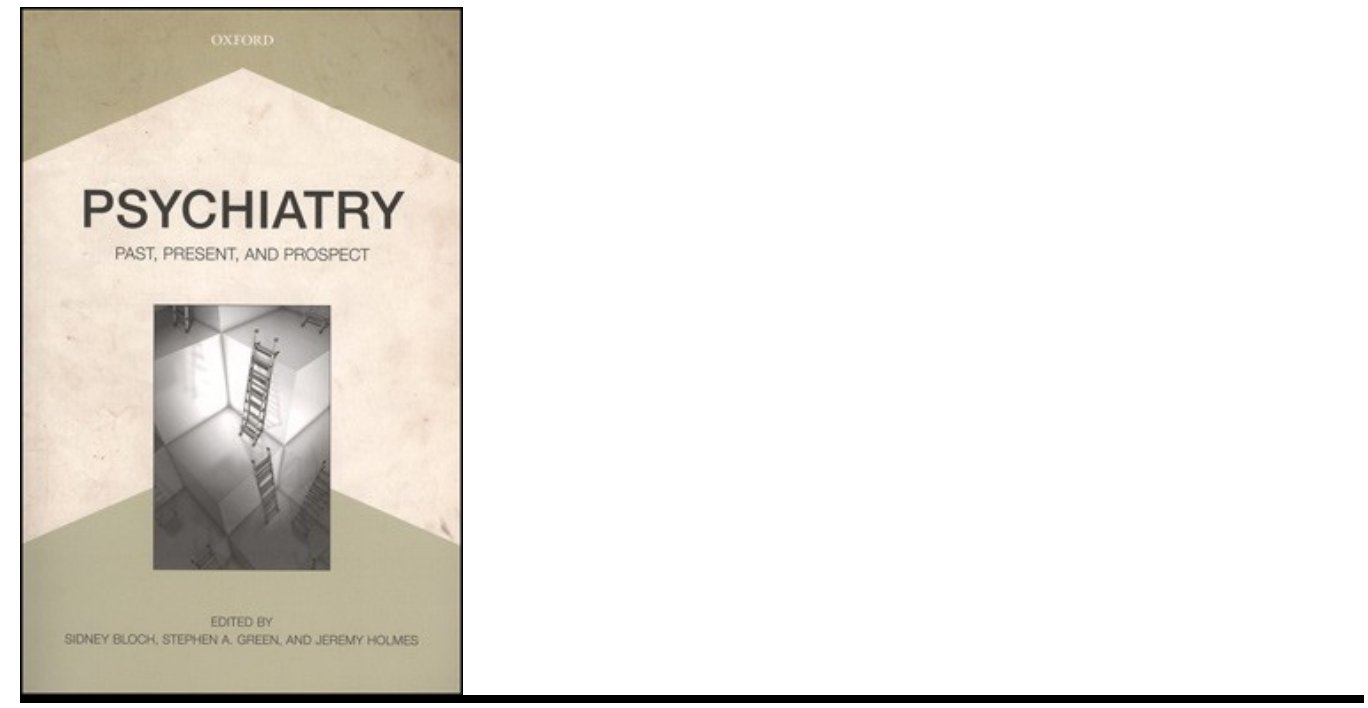

Bloch, Sidney

Green, Stephen A.

Holmes, Jeremy

Psychiatry

Past, present, and prospect. 413 s, ill. Oxford: Oxford University Press, 2014. Pris GBP 35

ISBN 978-0-19-9638963-3

Psykiatrien - akkurat som enkeltmennesket - bør jevnlig stille seg de sentrale eksistensielle spørsmålene: Hvor er jeg nå? Hvor kommer jeg fra? Hvor skal jeg hen? Denne boken gir ganske mange, nyanserte og tankevekkende svar på disse spørsmålene som vi psykiatere bør beskjeftige oss grundig med en gang iblant. 
Redaktørene var alle tre blitt emeriti og funderte hver for seg på å skrive sine faglige memoarer. Heldigvis kom de på ideen om å slå seg sammen og i tillegg be 25 andre fremragende kolleger om også å tenke tilbake på de siste 50 år og hvilken utvikling de selv hadde vært med på. Resultatet er blitt en meget kunnskapsrik, leseverdig og kritisk/sjarmerende gjennomgang av psykiatriens utvikling - kunnskapsmessig, tiltaksmessig og holdningsmessig - i de samme 50 årene som anmelderen selv har fulgt den.

Forfatterne har alle hatt topposisjoner innen sine fagfelt, men preges ikke av behovet for å ri egne kjepphester. I et sobert fagspråk oppsummerer de og ser med kritiske øyne på utviklingen og fremtiden innenfor en rekke felt: nevrovitenskap, genetikk, epidemiologisk og klinisk forskning, psykiatriens historie, transkulturell psykiatri, internasjonal psykiatri, sosialpsykiatri, familieorientert psykiatri, etikk, rettspsykiatri, tvangspsykiatri, barne-, ungdoms- og alderspsykiatri, psykoterapi (psykodynamisk, kognitiv, traumebehandling), misbrukspsykiatri, personlighetsforstyrrelser, psykofarmakologisk behandling og ECTbehandling, og ikke minst hele problemet med å definere, diagnostisere og klassifisere mentale lidelser. Alle forfatterne er bredt orienterte og advarer mot en biologisk reduksjonisme.

Det er først og fremst utviklingen innen angloamerikansk og australsk psykiatri som vi får beskrevet helt konkret. Forfatterne har selv hatt sentrale roller i denne. Referanser til annen faglitteratur er sparsom. Fra Norge nevnes eksplisitt bare Ødegaards undersøkelse av norske emigranter til USA (1932), statsminister Bondeviks offentlige omtale av sin depresjon og Reichborn-Kjennerud og medarbeideres tvillingstudie av forekomsten av symptomene ved ustabil personlighetsforstyrrelse i totalbefolkningen (2011). Svenske og danske kolleger er noe hyppigere referert til. Likevel viser denne gjennomgangen hvor sentral angloamerikansk, psykiatrisk forskning og klinisk arbeid har vært for oss i de siste 50 årene.

Boken illustrerer på en fremragende måte at slik psykiatrien nå ser ut for den unge nybegynneren, slik har den ikke alltid sett ut, og slik behøver den heller ikke å fortsette å være. Forhåpentligvis vil boken derfor stimulere og inspirere våre egne klinikere og forskere til å bringe faget stadig videre. Vil du vite hvor psykiatrien nå står, og hvor veiene kan gå videre, er dette boken å bruke noen timer på. Selv var jeg litt lei meg da jeg bladde om for siste gang.

Publisert: 30. september 2014. Tidsskr Nor Legeforen. DOI: 10.4045/tidsskr.14.0892

(C) Tidsskrift for Den norske legeforening 2023. Lastet ned fra tidsskriftet.no 26. april 2023. 